\title{
How security problem of Afghanistan threatens the global world: Afghan police reform case
}

\author{
İrfan Çiftçi ${ }^{1}$ \\ Sedat Kula ${ }^{2}$
}

\begin{abstract}
It is a fact that both the political and the security problems in Afghanistan have directly affected the stability of the region since Afghanistan is in the strategic position of Asia. The article presents an in-depth examination into the current situations of Afghanistan, particularly in regards to the nation's security dynamics. The U.S., the CSTC-A, GPPT, UNAMA, EUPOL, NATO and a lot of individual countries are interested in the reorganizing of the Afghan National Police (ANP) force with the aim of providing stability in the nation. The main problem is that each country or international organizations want to implement their own strategies and political purpose to rebuild the ANP. Therefore, Afghanistan faces enormous challenge in terms of security reform. After examining the security training efforts by international communities along with Turkey' contributions, recommendations are made to develop applicable, effective, and sustainable security reform that could be internalized by the Afghan officials.
\end{abstract}

Keywords: Afghanistan, Security, Police reform, Training, Stability

\section{Introduction}

Police reform is considered a critical element in reconstruction and peace building activities in postwar countries. Professional police organization contributes to sustain internal security and facilitate the transition from military to civilian life at the community level. Civil war which lasted 27 years destroyed security institutions particularly national and local police unit, army, and judiciary system in Afghanistan. Moreover, Afghan civil war divided country into more ethnic and political pieces.

Afghan National Police (ANP) is an integral part of defense against insurgency, narcotic crimes and organized crimes. Despite of assistance of international community, the contribution of

\footnotetext{
${ }_{1}^{1}$ Ph.D., Ankara Police Department, irfanciftci@yahoo.com,

2 Ph.D., Ankara Police Department, sedatkula@yahoo.com,
} 
Çiftçi, İ., \& Kula, S. (2014). How security problem of Afghanistan threatens the global world: Afghan police reform case. International Journal of Human Sciences, 11(2), 1041-1061. doi: 10.14687/ijhs.v11i2.2925

the U.S., and the European Union, ANP have still faced with corruption, incompetence and, have been far from the professional policing. Furthermore, ANP is unable to protect their Afghan citizen, to control crime, and to deal with the increasing insurgence. Therefore, there is a need to ensure stability and development in Afghanistan to build Afghan National Police.

This study aims to analyze how the ANP should be improved and reorganized. In collaboration with United States and other international organizations such as NATO, UN and the EU, Afghanistan has been in the stage of reorganization. The reorganization projects of the Afghan National are important due to the country's geopolitical position in the region.

Current situation and challenges facing the international police assistance program in Afghanistan are emphasized along with the brief history of policing in Afghanistan. The structure and shortcomings of Afghan National Police are discussed. After mentioning the contributions of international communities in Afghanistan, Turkey's contributions to rebuild ANP in the name of maintaining security in the region are addressed. Finally, some recommendations are made for corrective action to make the operations of international community in the police reform more effective and feasible.

\section{Security Problem in Afghanistan}

\subsection{A Brief History of Policing in Afghanistan}

Mohammed Ikbal, Pakistani Poet, says "there is a country in Asia, if there is a peace in that country, whole Asia will be in a peace, if there is not, it would not be peace in Asia. In this case, it is important to keep this heart well" (Yllmaz, 2005). The great empires such as Mongols, Baburs and the Romans had invaded the Horasan City for centuries. Invasion of the British and the Russians gave way to internal conflicts, wars and occupations in Afghanistan for years. Ending wars and occupations and ensuring peace in Asia have always been a challenge.

During 1960s and 1970s, national civilian police force was responsible for security in Afghanistan. The national police force was built upon to European policing model by East and West Germany (Murray, 2007, p. 109). Both the Federal Republic of Germany and German Democratic Republic helped to Afghanistan to improve police development program. During the Soviet period, the ANP was organized by modeling the Soviet structure which has two systems of carrier officers and conscripts. While officers were trained at the Police Academy; conscripts served two years as a patrolmen, and they trained by superiors. Thus, the police were militarized, and started their disintegration and deterioration as a civil institution (Perito, 2009). Following Soviet withdrawal in 1989, Afghanistan started again to establish police force, and the Police Academy was built in Kabul by Germans. During the civil war and the period of Taliban, there was no police 
Çiftçi, I., \& Kula, S. (2014). How security problem of Afghanistan threatens the global world: Afghan police reform case. International Journal of Human Sciences, 11(2), 1041-1061. doi: 10.14687/ijhs.v11i2.2925

force in Afghanistan (Wilder, 2007). After the period of Taliban in 2002, there were 50,000-70,000 police. The majority of them were illiterate ( 80 percent) and untrained, and they had no uniforms, discipline, facilities, equipment, and lacked of formal police skills and public trust. Another important problem for Afghan Police was ethnic imbalance. The most of commanders of Afghan Police were Tajik Afghans. Moreover, the local commanders and warlords had access more money than government. Civil war and the jihad against the Soviet Union had intensified ethnic tension and pushed local commanders to create their own militias. Therefore, the central control and systematic chain of command did not exist within Afghan Police under the Ministry of Interior (Murray, 2007, pp. 109-110).

Perito (2009) states the Agreement on Provincial Arrangements in Afghanistan Pending Reestablishment of Permanent Institutions signed by the delegates of the Afghan people in 2001, in Bonn, Germany as the Afghan Police Reform`s starting point by saying that

"Officials in the Afghan Interim Authority recognized that international assistance would be required to create a new Afghan National Police. The Afghan Interim Authority wanted to create a new professional police service with educated officers and trained career noncommissioned officers and patrolmen. Based upon the positive experiences with German police assistance prior to the Soviet intervention, the Afghans welcomed Germany's selection as the lead nation for training and equipping the Afghan police" (p. 23).

A new comprehensive plan to rebuild Afghan National Police Force was prepared in 2002 by the German Government. The plan consisted of five main issues: advice on structure and organization of the force; the rehabilitation of Kabul Police Academy; the reconstruction of police buildings and institutions; the provision of equipment such as police vehicles; and coordination of all other donor activities that relate to policing (Sedra, 2003). The rehabilitation of Kabul Police Academy and police trainings were the most significant parts of the German program. Comprehensive training plan for the Afghan National Police aimed to create the Police Academy based on European Model that would offer 4 year university level training.

The comprehensive framework of the security sector reform of Afghanistan was set by 'lead nation' at the G8 donor's conference in Geneva in 2002. According to Security sector reform plan, the United States would be responsible for the military; Germany would reorganize the police; and Italy would reform judiciary. All donor countries were expected to share the burden to rebuild the security sectors in Afghanistan. Following years, the focus of attention of the United States and other international donors shifted from professional policing to operational policing, owing to the rapidly increase of security problem in Afghanistan (Hayes \& Sedra, 2008).

The establishment of the Law \& Order Trust Fund (LOTFA) for Afghanistan in December 2002 was also considered an important milestone for Afghan Police Reform. The main objective 
Çiftçi, İ., \& Kula, S. (2014). How security problem of Afghanistan threatens the global world: Afghan police reform case. International Journal of Human Sciences, 11(2), 1041-1061. doi: 10.14687/ijhs.v11i2.2925

of the LOTFA, which was managed by the UN Development Program, was to cover budgetary expenses and salaries in security sector, to rehabilitate police buildings, to train police, and to develop law enforcement capacity in whole country. Before the establishment of the LOTFA, the Afghan Interim Administration could pay only $10 \%$ of operational police cost. Therefore, the first priority of the LOTFA was salary cost. Even though the fund was not only a solvent per se, the Interior Ministry would not be able to sustain regular salary payment without the support of LOTFA (Murray, 2007, p. 110).

Another important milestone was that Ali Ahmad Jalali, former professional military officer and a Pashtun Afghan-American journalist, was appointed as a Minister of Interior in 2003. Seven months later after his assignment, he proclaimed a plan of security reform. The main goals of his plan were to recruit 50,000 police force instead of conscripted solders, and to train 40,000 recruited police force in Kabul and other eight in-service training centers established by the US. Other important parts of the projects were creating national counter-narcotic, counter-terrorism and human rights unit and forming the National Security Directorate (NSD), a mixed model of the FBI and the CIA, related to national intelligent service. Currently, the NSD, having 23 directorates and 30,000 employees, is the most important and powerful institution in Afghanistan (Sedra, 2003, p. 34; Murray, 2007, p.111-112).

\subsection{Current Situation in Afghanistan}

Both the political and the security problems in Afghanistan have directly affected the stability of the region since Afghanistan is in the strategic position of Asia. Owing to the transition rote of energy and the geopolitically importance, Afghanistan is a vital bridge between Euro-Asia and North-South. After the terrorist attacks of 9/11, the United States and several allies entered Afghanistan to destroy the Al-Qaeda terrorist organization and its leader Osama bin Laden, and they overthrown the Taliban regime that supports terrorist activities. After the overthrow of the previous government, the interim Afghan government was established under the supervision of international powers. The current president Hamid Karzai was appointed as the head of state of the interim government for 6 months. Karzai was elected as the new president of Afghanistan as a result of election held on 11 June 2002 (Goodson, 2005, p.24).

The United Stated, NATO and other donors tried to develop new security strategies which can rapidly provide stability in the country. As the security in all over the country is becoming worse, Afghanistan is the initial issue of the agenda for the US, NATO, and for the EU. Despite all efforts of the international community, the security of the country cannot be completely maintained. Currently, some parts of Afghanistan are being controlled by the Taliban groups or 
Çiftçi, I., \& Kula, S. (2014). How security problem of Afghanistan threatens the global world: Afghan police reform case. International Journal of Human Sciences, 11(2), 1041-1061. doi: 10.14687/ijhs.v11i2.2925

other insurgents. They are attacking the US` soldiers, international peace forces and the Afghan security forces, particularly against the ANP. The Taliban groups and insurgents are controlling only a little part of the country which is near the Pakistani border (Pandya, 2004). The country's geographical structure is one of the significant factors preventing to struggle the attacks. The actions of suicide usually by car or on foot (suicide bomb), are still alive especially in Kabul. However, it can be said that the safest location is the Kabul region in Afghanistan and the region is being supervised by the International Security and Assistance Force (ISAF) (Rubin, 2003).

ISAF was established by UN Security Council Resolution of December 20, 2001, authorized for six months to assist the new Afghan government in order to maintain security. After its establishment, ISAF begun to serve in Kabul, and had 5,000 troops from nineteen countries. ISAF is responsible for providing security in the capital where it conducted routine patrols with local police. However, there was really difficult to maintain the security with new lead nations. In August 2003, the command of the forces changed hands indefinitely to NATO to solve the security problem. So, NATO was the first deployment outside Europe or North America (Perito, 2009, p. 2). Because of its expanding responsibility, ISAF took command of an increasing number of "Provincial Reconstruction Teams (PRTs)"in order to sustain security and facilitate reconstruction in provinces. The expansion of ISAF to all regions of the country has brought the total number of PRTs to twenty-seven (See Figure 1).

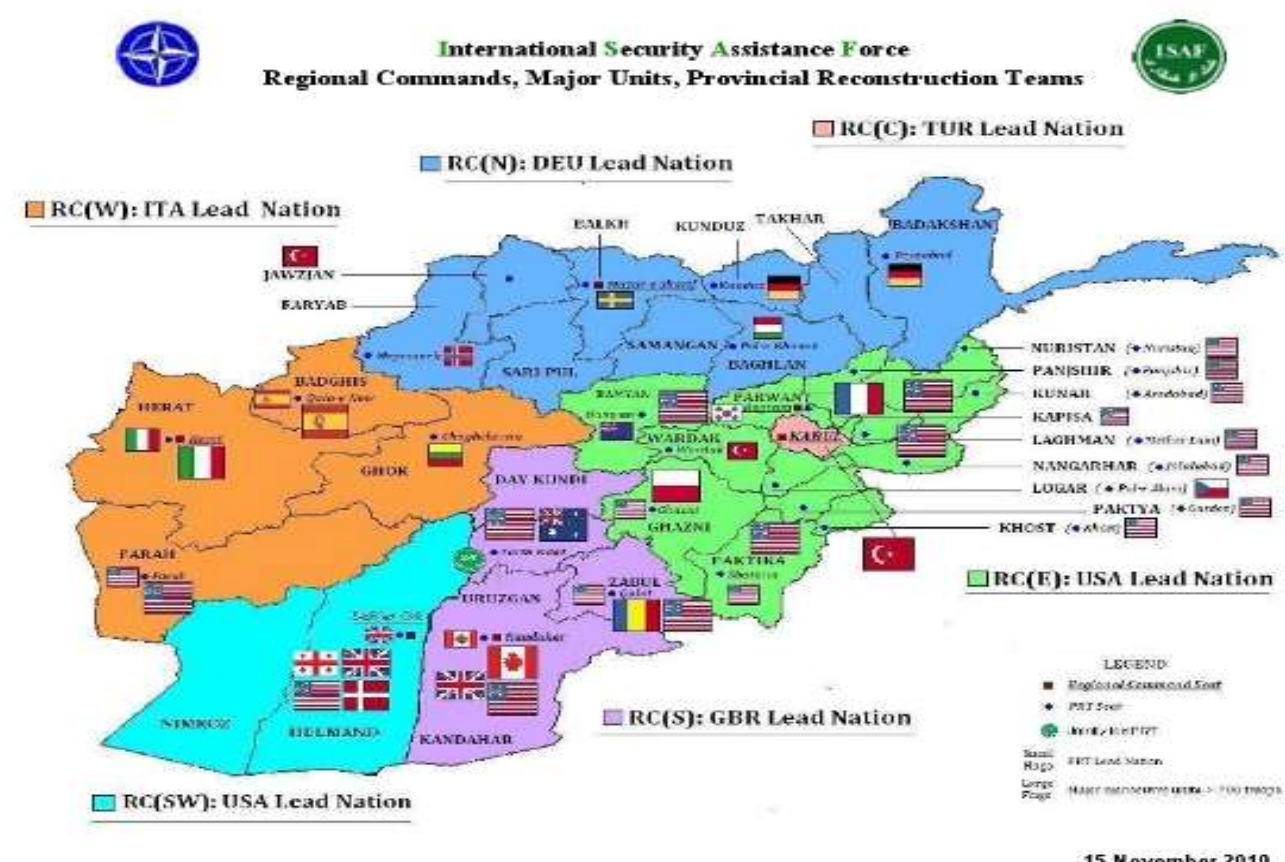

Figure 1: The Regional Lead Nation of ISAF Source: from IS AF Official Website 
Çiftçi, İ., \& Kula, S. (2014). How security problem of Afghanistan threatens the global world: Afghan police reform case. International Journal of Human Sciences, 11(2), 1041-1061. doi: 10.14687/ijhs.v11i2.2925

ISAF, the international power, currently serves 130,930 persons with 48 nations contributions, 90,000 from the US (http: www.isaf.nato.int, 2010).

\subsection{The Organizational Structure of the Afghan National Police}

According to Murray (2009), "In democracies, there is usually a separation between policy and operational direction of the police. While policy direction is the responsibility of the government, operational direction is the responsibility of the chief of police." However, in Afghanistan, the situation is different; these two functions are not separate from each other. The Minister of Interior is both the president of the cabinet and the head of the operational police. Hence, "no system of checks and balances, no government oversight of operations and little policy expertise at senior levels of the ministry exist” (Murray, 2009, p. 194). The Afghan National Police is responsible to the Minister of the Interior which consists of three deputy ministers and, police services are under the responsibility of a deputy minister for security. Police managers at the provincial organizations are accountable to deputy minister who is carried responsibility police services (Figure 2).

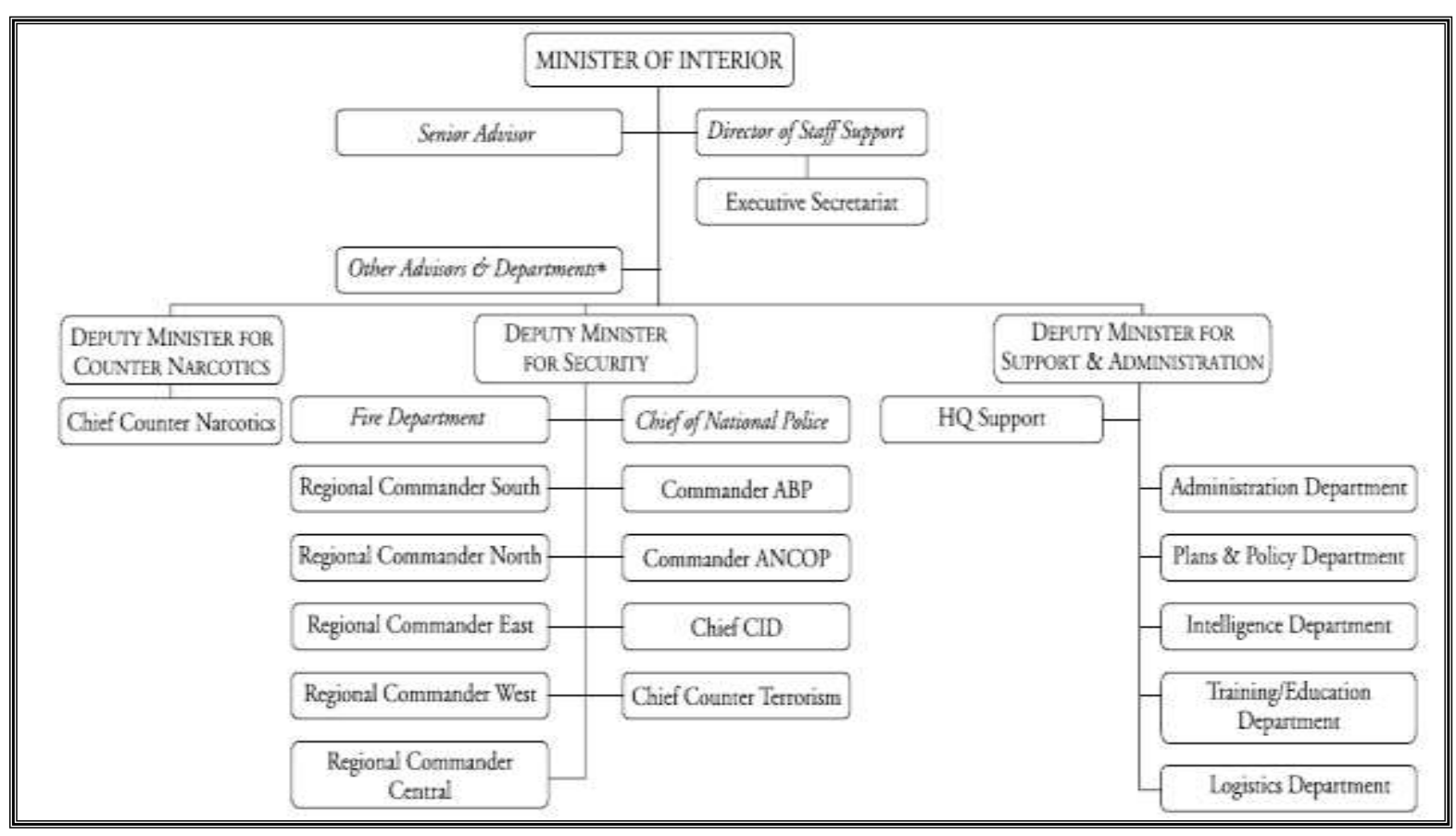

Figure 2: Organizational Structure of the Ministry of Interior Affairs

Source: Murray (2009)

Afghanistan in the vicinity of approximately 82,000 police is on duty with an Auxiliary Police. The US and other donors have financed the payment of police salaries since beginning of the police reform since 2002. The Law and Order Trust Fund of Afghanistan (LOTFA) managed 
Çiftçi, I., \& Kula, S. (2014). How security problem of Afghanistan threatens the global world: Afghan police reform case. International Journal of Human Sciences, 11(2), 1041-1061. doi: 10.14687/ijhs.v11i2.2925

by UNDP have supported the Minister of Interior to pay police salaries. By means of the rank reform and pay reform decreased the number of a "bloated" officer cadre. For example, the major`s monthly salary was $\$ 84$, patrolmen's salary was $\$ 70$. As a result of the low pay salary, bribery and corruption within the police was common. Table 1 indicates the salary rates of Afghan police before and after reform.

Table 1: Police Rank and Pay Structure Before and After Reform:

\begin{tabular}{|c|c|c|c|c|c|}
\hline Rank & $\begin{array}{c}\text { Pay Before } \\
\text { Reform (USD) }\end{array}$ & $\begin{array}{c}\text { Pay After } \\
\text { Reform (USD) }\end{array}$ & $\begin{array}{c}\text { Number } \\
\text { Before Reform }\end{array}$ & Rank & $\begin{array}{c}\text { Number } \\
\text { Afier Reform }\end{array}$ \\
\hline Lt General & $\$ 107$ & $\$ 750$ & 319 & Generals & 120 \\
\hline Maj. General & $\$ 103$ & $\$ 650$ & 2,447 & & \\
\hline Brig. General & $\$ 95$ & $\$ 550$ & 1,824 & & \\
\hline Colonel & $\$ 92$ & $\$ 400$ & 2,067 & Colonel & 235 \\
\hline Lt. Colonel & $\$ 88$ & $\$ 350$ & 3,762 & Lt. Colonel & 305 \\
\hline Major & $\$ 83$ & $\$ 300$ & 1,705 & Major & 474 \\
\hline Captain & $\$ 78$ & $\$ 250$ & 1,834 & Captain & 1,140 \\
\hline $1^{\text {st }}$ Licutenant & $\$ 69$ & $\$ 200$ & 1,043 & $1^{\text {st }}$ Lieutenant & 1,710 \\
\hline \multirow[t]{2}{*}{$2^{\text {nd }}$ Lieutenant } & $\$ 66$ & $\$ 180$ & 4,813 & $2^{\text {nd }}$ Lieutenant & 2,836 \\
\hline & & & & $3^{\text {rd }}$ Lieutenant & 0 \\
\hline \multirow[t]{3}{*}{ Sergeant } & $\$ 62$ & $\$ 115$ & 36,600 & Sergeant & 9,300 \\
\hline & & $\$ 140$ & & & \\
\hline & & $\$ 160$ & & & \\
\hline \multirow[t]{2}{*}{ Patrolman } & $\$ 70$ & $\$ 70$ & & Patrolman & 45,880 \\
\hline & & $\$ 80$ & & & \\
\hline
\end{tabular}

Source: from Murray 's Article, Security Sector in Afghanistan

According to Afghan Law, the main role of the (ANP) is "to maintain civil order and public safety, protect the rights of citizen, support actions against insurgency, control national borders, and reduce the level of transnational and domestic crimes"(Afghanistan Security Report, 2008, p. 8). However, the Afghan government needs more time to implement to these roles, and to maintain security and public safety.

The organization structure of Afghan police was developed according to the military structure by the Afghan government and international donors, because in the case of shortage of military personal to counter the insurgency, the Afghan government and the US use easily them in counter-insurgency operations.

\section{International Power's Contributions to build the ANP}

Reconstruction projects in Afghanistan since 2002, many states exhibit intensive efforts for developing and implementing these projects. The security sector reform of Afghanistan was divided into five sections: The U.S. was responsible for Afghan National Army (ANA); Germany, the ANP; Italy, the National Justice System; Japan, disarmament of illegal military groups; and the U.K., 
Çiftçi, İ., \& Kula, S. (2014). How security problem of Afghanistan threatens the global world: Afghan police reform case. International Journal of Human Sciences, 11(2), 1041-1061. doi: 10.14687/ijhs.v11i2.2925

counter illicit drug trafficking. Excluding Japan's disarmament projects, other all projects are currently ongoing.

In addition to Germany, the U.S., the CSTC-A, GPPT, UNAMA, EUPOL, NATO and a lot of individual countries by means of bilateral agreements have been interested in the reorganizing of the Afghan National Police (ANP). One of the main reasons that slow process is undoubtedly having several stakeholders. Each country wants to implement its own strategies and political purpose to rebuild the ANP. Today, this is also enormous challenge in Afghanistan in terms of security reform.

Thruelsen suggests that

"Multilateral agreements lack muscle, while bilateral agreements undercut the multilateral framework. Many bilateral agreements reflect the specific national agendas of the countries involved, keen to 'show the flag', and only a few want to be subject to EUPOL control. Each country would rather make its own bilateral commitments to the Afghan government, which leaves too many actors driven by individual strategies involved in the same project” (p. 85).

\subsection{European Union Police Mission Efforts}

The European Union Council, in February 2007, created the European Security and Defense Policy mission to build the ANP. Germany was a "key partner" of this police rebuilding reform program. There are currently 400 international staff, 218 police officers within the EUPOL from sixteen EU member countries and seven others. The main emphasis of the EUPOL is to give advice and support including criminal investigation for ANP (Crisis Group Asia Report, 2007, p. $10)$.

In May 2008, the EU decided to increase the size of police mission. With the appointment of new commander from Denmark, who had great experience related to international policing missions, in October 2008, EUPOL tried to use its western type policing expertise, which has linkages with the judicial sector, to strengthen the interior ministry and provincial police chiefs in the urban centers (Crisis Group Asia Briefing, 2008, p. 10-11). However, EUPOL had difficulty to set up working relationships with the NATO. Moreover, European people were not happy for their police, soldier and staff serving in Afghanistan. Besides, the main problem was that EUPOL had different aims for implementing the program among member countries. Since the creation of the NATO Training Mission-Afghanistan (NTM-A), in 2009, the role of the EUPOL in police assistance program have been more complicated (Perito, 2009, p. 11).

\subsection{The International Policing Coordination Board (IPCB)}

In 2007, due to the increasing need for coordination among international organizations in Afghanistan, the International Policing Coordination Board (IPCB) was established with the 
Çiftçi, İ., \& Kula, S. (2014). How security problem of Afghanistan threatens the global world: Afghan police reform case. International Journal of Human Sciences, 11(2), 1041-1061. doi: 10.14687/ijhs.v11i2.2925

contribution of eight members: the United Nations Assistance Mission to Afghanistan (UNAMA), ISAF, NATO, the U.S. embassy, CSTC-A, The European Union Special Representative (EUSR) and European Commission, it is chaired by the minister of interior (Crisis Group Asia Briefing, 2008, p. 11).

Even if the aim of the IPCB was to coordinate the international organization which dedicated to rebuild the ANP, so far it has been slow to take hold. Around twenty persons who are serving at the IPCB`s secretariat have a uncertain role. Although the secretariat has provided the standardization in curriculum between the various countries, their operations are not satisfying among different nations. The lead nations could not desirably contribute to the coordination board. However, "with key international actors and donors coming from differing policing traditions and offering multiple, sometimes overlapping programs, it is vital that all work together to make the IPCB a forum for real coordination and planning”(Crisis Group Asia Report, 2007, p. 9).

\subsection{The Activities of the Provincial Reconstruction Teams (PRTs)}

The Provincial Reconstruction Team enterprise is a civil-military activity that is becoming as a primary mediator between the U.S. or donors and provincial governments throughout Afghanistan. In other words, PRTs in Afghanistan are a significant factor through which the international donors deliver assistance at the district and provincial level. As a result of their provincial interest and civilian and military resources, PRTs have a unique mandate to rebuild security, support good governance, and improve provincial development. The combination of international military and civilian resources also allows the PRTs having wide latitude to implement their mandate. The PRTs are usually located in a province in Afghanistan. Currently, 27 PRTs are operating in Afghanistan. The main goal of the PRTs is to "seek to establish an environment that is secure and stable enough for the operation of international and Afghan civilian agencies to provide development support"(USAID, 2010). The last $27^{\text {th }}$ PRT was opened by the Turkish government in Cevizcan province on July 21, 2010.

Increasing security concerns in Afghanistan has again revealed the importance of professionalization in good management and training of police organization. The U.S., the EUPOL and others donors arrange short term and long term police training activities in PRTs. These trainings are given by instructors both from army and civilian police organization. The Turkish PRT, for instance, has 20 expert trainers from various police department such as Special Forces, Organized Crimes, Crime Scene Investigation, contingency force, and crime prevention. In addition, the Turkish PRTs have a special police team which contains twenty people, one police officer to carry out administrative tasks, and one police chief to coordinate and manage of all police 
Çiftçi, İ., \& Kula, S. (2014). How security problem of Afghanistan threatens the global world: Afghan police reform case. International Journal of Human Sciences, 11(2), 1041-1061. doi: 10.14687/ijhs.v11i2.2925

services in order to maintain security Wardak and Cevizcan provinces. Turkish police officers served at the PRTs train the ANP in basic police skills, including crime investigation, management skills, evidence collection, operation techniques, and crime prevention. Apart from the Turkish PRTs, all donor`s PRTs have more than 5 police instructor, advisor, and solder trainers. Thus, in this purpose, the main objective of the PRTs is to train provincial police forces to maintain security in that region.

In addition, Italy, the U.K., Canada, and other coalition partners contributed to police assistance program. Police training and mentoring teams from these countries were deployed to their own Provincial Reconstruction Teams (PRTs), where they managed police training and offered equipment and technical assistance. "These bilateral efforts, which varied in size, were not always coordinated with the larger U.S. and EU programs. In general, they stressed the importance of community policing and taught civilian police skills, but they also reflected differing national policing philosophies and practices, adding on another level of confusion to an already bifurcated program" (Perito, 2009, p. 11). Currently, whilst Italy conducts the police assistance program in their PRT, in Herat, established in 2005, Canada offers their police assistance program in its own PRT in Kandahar province. Like the Canadians in Kandahar province, the British in Helmand province conduct their program through their PRT. All of these countries train the Afghan provincial police forces in basic policing skills.

\subsection{The Auxiliary Police (ANPA) and the Public Protection Program (AP3)}

By 2006, not only the ANP but also the U.S. and international organizations, could provide security in the country. In this respect, the U.S. developed new approaches to maintain security in Afghanistan. The first, the most important one, was the creation of the ANP Auxiliary which they deployed the high risk district in 21 provinces in order to provide security and to fight particularly insurgents. However, there is a big challenge between the ANPA and the regular ANP officers. The ANP officers have questioned "why the ANPA received the same salary and wore the same uniform". The main purpose of the ANPA is to control and secure checkpoint, to release the ANP for counterinsurgency operations. By 2007, 8300 ANPA members was trained by the U.S. instructors, theoretical aspects such as ethics, police techniques, the Afghan constitution, and practical trainings such weapons, shooting, operation (Perito, 2009, pp. 9-10).

Later, in 2009, the U.S. created the Public Protection Program (AP3) as a result of the failure of the ANPA project. The program aimed that the villages would create self-defense forces to defend their villages against Taliban insurgents. The members of the Public Protection Program were recruited by "tribal councils" (shuras) (Perito, 2009, p. 9). The program is also continuing as a 
Çiftçi, İ., \& Kula, S. (2014). How security problem of Afghanistan threatens the global world: Afghan police reform case. International Journal of Human Sciences, 11(2), 1041-1061. doi: 10.14687/ijhs.v11i2.2925

pilot project in Wardak Province, the vital route for suicide bomber into Kabul, and the program is run by the CSTC-A and Turkish Wardak PRT.

\subsection{The International Police Training Efforts}

Police training is a core component of the Afghan Security Reform. Germany has interested in police training of the ANP since "the Soviet invasion", and the German government, by 2002, sent again their police trainers and advisers to Afghanistan to build the ANP. They started to reconstruct and equip some police facilities and advise institutional change. Beside these efforts, the Germany focused on the Kabul Police Academy, reopened in August 2002, offering three years courses for officers nine month courses for non-commission officers. The German`s plan reflected the European model policing and required long term process. However, the U.S. officials in Afghanistan thought that the German approach related to police reform was not inappropriate for Afghanistan. However, the U.S. did not challenge the German approach, and established the Central Training Center (CTC) in Kabul and seven Regional Training Centers, Gardez, Kunduz, Jalalabad, Mazar-i Sharif, Kandahar, Herat, and Bamiyan, to train police rapidly after 2003 (Crisis Group Asia Report, 2007, p. 7). The U.S. contracted the DynCorp, private company, to train and to oversee the regional police forces.

In-Service Training Center, the CTC was established on very large area and had very modern equipped containers. In the Training Center, Americans and international trainers have been serving since 2003. Trainings were planned in three modules: 5 week course for illiterate patrolmen and non-commissioned officers; 8-week course for literate officers; and 2 week course for to develop their basic police skills. Apart from these, the center also offered training of instructor programs; two and four week course. Until 2007, 71.147 Afghan police were trained by Americans and international trainers (Perito, 2009, p. 4). However, the quality of these trainings was questioned by many raining experts and international authorities. With Peritos remarks "Trainees had little or no classroom experience. They sat on hard benches for hours a day in prefabricated classrooms that baked in the summer and froze in the winter, listening to instructors who spoke in English and poorly trained Afghan translators unfamiliar with police terminology. Few of the American instructors were Professional police trainers, and there was little or no use of adultlearning techniques. Because more than 70 percent of the Afghan trainees were illiterate, most of those trained received only the fifteen-day program". The other problem was that "the inability of recruits to read and write inhibited their ability to absorb information and learn basic police skills, such as taking statements from witnesses, writing incident reports, and maintaining records" (Perito, 2009, p. 4). 
Çiftçi, I., \& Kula, S. (2014). How security problem of Afghanistan threatens the global world: Afghan police reform case. International Journal of Human Sciences, 11(2), 1041-1061. doi: 10.14687/ijhs.v11i2.2925

The U.S. spent much more money than other international donors for the Afghan National Police Reform. For instance, while the U.S. supported to the Afghan National Police $\$ 2.1$ billion between 2002 and 2006 trough CSTC-A (Combined Security Transition Command-Afghanistan), Germany spent $\$ 90$ million on police reform in Kabul and northern Afghanistan. Beside this, while the CSTC-A `s 100 personal and 500 contract trainers focused on police trainings, the Germans has around 40 officers in Kabul Police Academy (Crisis Group Asia Report, 2007, p. 7).

\section{6. 'Turkey' Contributions for ANP Training}

The NTM-A have dealt with the reform of the ANP since 2009, and tried to coordinate the training assistance in Afghanistan. The last activity of the NTM-A, for instance, was to send around 600 Afghan police to Turkey in order to have a training for six month, in September 2010. Due to the need to increase capacity of the Afghan National Police (ANP), Afghan Ministry of Interior and NATO Training Mission-Afghanistan started to look outside of the Afghanistan for training opportunities. In a conversation between Turkey and NTM-A, Turkey proposed to host and train ANP Officer. Because, Turkey promised the Afghan government in the Triple Summit (TurkeyPakistan-Afghanistan) Conference in Istanbul, in April 2007, for training 15.000 Afghan police within 5 years.

“Turkey's proposal was for 'all inclusive' training, where essentially Ministry of Interior and NTM-A select and in-process the students, and deliver them to Ankara with the clothes on their back and minor items for a six month course to produce Afghan Uniform Police Officers"(http://www.ntm-a.com, 2010).

One of the main criticisms to police training across the world is that there is a gap between the training given in police training institutions and what police do in real life. Basic law enforcement training is not really associated with the real life that the new officers will face when they begin to work.

Law Enforcement Agencies are expected to prepare their workers to carry out their missions perfectly under stressful and severe circumstances. Law Enforcement Agencies, more than other organizations, need to have skilled people in order to serve the public. The demands placed on police officers in today's society require them to acquire and maintain a vast amount of knowledge. To be effective and safe, they must learn quickly and be able to relate their knowledge to field situations. Providing the transition between academic knowledge and real life is crucial for police training. Many law enforcement agencies spend millions of dollars to develop and design new police training curriculum to train their personnel to meet the increasing demands of society. 
Çiftçi, İ., \& Kula, S. (2014). How security problem of Afghanistan threatens the global world: Afghan police reform case. International Journal of Human Sciences, 11(2), 1041-1061. doi: 10.14687/ijhs.v11i2.2925

Turkish National Police (TNP), with more than 250.000 employees across the country, is one of the leading police organizations in the region trying to adopt new trainings methods and techniques to train and prepare their personnel to meet the high expectations of society. Not only TNP tries to increase the level of their personnel in terms of training, but also it shares its experiences with other countries' police organizations. Modular training, which combines the theoretical knowledge and practical applications in a comprehensive way by field experts, is one of the new methods that have been used by TNP for police trainings over the last years (Kula ${ }^{3}$, Personal Experience, 2014).

Within the frame of comprehensive development assistance program in Afghanistan by the Republic of Turkey, "Afghan Police Training " is an important project for the future of Afghanistan and its people. Based on this project, every year it is planned to train 1000 Afghan Police Candidates for the following 5 years as a part of Turkey's contribution to the reconstruction of Afghanistan. The Government of The Republic of Turkey and Government of The Islamic Republic of Afghanistan signed the Memorandum of Understanding on 5th of March 2011 to establish peace and stability for Afghanistan through capacity building for Afghan National Police Force (Official Gazette of the Republic of Turkey). As a well-organized, professional, well-trained and equipped national police force, TNP aims to share its experiences and to put effort to create a respected and competent Afghan police force dedicated to the rule of law and human rights (Kula, Personal Experience, 2014).

After the Memorandum of Understanding signed between the both governments has been found appropriate by the National Assembly of the Republic of Turkey, one of the greatest Police Training Centers, Sivas Police Vocational Training Center was reserved and allocated to train Afghan Police candidates. Afghan police candidates started their training in Sivas Police Training Center. Sworn and non-sworn officers were assigned by TNP to handle the administrative services required throughout the training period of 6 months. Afghan administrators helped the Turkish Staff in implementing the rules related to training (Kula, Personal Experience, 2014).

Beside the 'Turkish National Police' contributions, this training was financially contributed by Combined Security Transition Command for Afghanistan (CSTC-A) and Law and Order Trust Fund for Afghanistan (MoI-LOTFA). Japon Government also provides judo trainers to give judo training to Afghan Police candidates. Language interpreters were assigned by CSTC-A to facilitate the training. It is noteworthy to claim that developed training is relevant to the current security situation in Afghanistan and its needs since the training program is developed according to

\footnotetext{
${ }^{3}$ Sedat Kula worked at the International Training Division under the Training Department of Turkish National Police. He worked as a member of Afghan Police Training Project.
} 
Çiftçi, İ., \& Kula, S. (2014). How security problem of Afghanistan threatens the global world: Afghan police reform case. International Journal of Human Sciences, 11(2), 1041-1061. doi: 10.14687/ijhs.v11i2.2925

training needs assessment. The training program is developed as modules. The trainers of each module are selected and assigned across the country based on the extensive training backgrounds and field experiences. By doing this way, all courses were taught by experts who have both academic and field knowledge. Afghan Police candidates had taken test or practical examination at the end of each module or course based on the modules and contents of the courses. Selecting and assigning the instructors for each module across the country is the major advantage of the program. This provides the managers of the program an opportunity to find and select the best instructors across the country related to the course contents. All Afghan Police candidates exposed to comprehensive training for each module. All of the modules are also practical oriented. They have opportunities to apply what they learn. Majority of instructors have "Training of Trainers" certificate which means that instructors have the abilities of using new trainee-oriented teaching methods (Kula, Personal Experience, 2014).

Training modules and courses are designed by TNP experts to cover the basic and advanced police topics that are taught in most western police training institutions. The basic course modules include topics such as human rights and police ethics, first aid, policing in multi-cultural societies and community policing, communication skills, police defense tactics, stopping and controlling the vehicles, controlling the traffic and accident analysis, behavioral pattern and massed formation, and introduction to firearms and basic shooting. Advanced course topics are tactics for intervening the social disturbances, criminal investigation and statement analysis, bombs and explosives, narcotics and organized crime investigations, crime scene investigation and evidence gathering, and leadership and management competencies, combating terrorism (Kula, Personal Experience, 2014).

To evaluate the training, Kirkpatrick's four-level training evaluation method was used. At the beginning, the reactions of Afghan Police Candidates are tried to be understood how they perceive and mean the relevance and quality of the training. To what extent the candidates' attitudes, knowledge, and skills are changed as a result of training is evaluated in the second level of evaluation. For the third level of Kirkpatrick's evaluation model, the question- How often do Afghan Police Officers use the knowledge and skills gained at the trainings is tried to be answered to measure the changes in their job behavior or performance. Self-assessment questionnaire, onthe-job-observation, and reports from their immediate supervisors are used. The purpose of the final level of evaluation is to evaluate trainings from organizational point of view. Evaluations will be made how the ANP get benefited from the results of Training after one year from graduation by making interviews with the heads of Afghan National Force, NTM-A and other related organization' authorities (Kula, Personal Experience, 2014). 

case. International Journal of Human Sciences, 11(2), 1041-1061. doi: 10.14687/ijhs.v11i2.2925

Modular training is a training model for police organizations that are keen to teach and improve their candidates in the light of contemporary policing approaches which include the notions of democratic policing, community policing, and problem-oriented policing. Each module either as a whole or in part is adapted from in-service training courses given by different department of TNP. This gives the training program an exceptional benefit from different aspects. First, each department that is responsible for its module assigns their training instructors who have practical experiences and years-long teaching experiences in their own fields. Second, rich course materials prepared by each department are used for trainings, which increase the quality of the program. Since modules are adapted from specialized in-service training courses, they include the practical applications of their relevant course subjects.

\section{The Obstacles of The Police Reform}

Police reform is one of the most significant and complex challenges especially in postconflict region where the police forces have frequently committed serious human rights violations or illicit activities. In those regions, police operations are tend to be like military contingents. In post conflict and within conflict regions such as Afghanistan, Iraq, local and international authorities have spent much more effort to transform such police forces into democratic police services (O’neill, 2005, p. 2).

International community, particularly the U.S., has increasingly focused on the police reform to maintain security in Afghanistan since 2005. However, in one hand while they are trying to re-build the Afghan National Police, on the other hand they are dealing with lots of obstacles such as shortfall in resources, lack of coordination among donors, corruption and drug trafficking, and illiteracy.

\subsection{Shortfall in Resources}

The problem is "that countries often want their names up in lights next to their pet programs, sometimes administered by their own NGOs, everyone wants to send their children back to school; no one wants to pay military or police salaries" (Chesterman, 2002, p. 7). Although more than 40 nations and international organizations and NGOs have offered funds, personnel, or equipment to support America`s efforts to train and equip, the problem still has not been solved in the country. Therefore, as a natural result of the lack of resources, in many regions of the country local governors have borrowed money from regional tradesmen and abused police files and rank (Amnesty international report, 2002). Hence, this problem has pushed the police forces and local governments to corruption. 
Çiftçi, İ., \& Kula, S. (2014). How security problem of Afghanistan threatens the global world: Afghan police reform case. International Journal of Human Sciences, 11(2), 1041-1061. doi: 10.14687/ijhs.v11i2.2925

Another significant problem for the U.S. and the Afghan government is lack of police mentors who provide training in the field and confirm "that police are on duty". Police mentors are also important argument for the U.S. Defense Department. Additionally, according to the Defense Department, one-third of the Afghan Police Forces have still had the equipment items, such as trucks, radio, and body (Afghanistan Security Report, 2008, p. 31).

\subsection{Poor Coordination among Donors}

Coordination is another persistent problem that shows no sign of disappearing. Donors' efforts in Afghanistan and its provinces have been almost for a specific purpose and defined by national interests. Because of poor coordination among donors and a lack of transparency in aid spending have seriously affected aid efficiency. Murray observes that:

"Germany and the United States had developed parallel reform schemes. There was a German senior adviser 'embedded' in the ministry for administrative reform but the Minister had also acquired an American adviser during the course of 2003. .....While the Germans had spent $\$ 3$ million on the Academy and other amounts on other projects including $\$ 460,000$ on ministry reform, the United States was spending millions more, although not necessarily any more strategically. Evidently, two different approaches to police-building were developing. One cautious and rational, building on what already existed and extending outwards, and the other bold and sweeping, attempting to tackle a number of pressing problems all at the same time"(Murray, 2007, p. 112-113).

The Centre for International Governance Innovation (CIGI) report indicates this situation as; "The endless stream of coordination structures and meetings has only made a minor contribution to untying this Gordian knot; what has been missing is leadership, particularly from the heavyweight donors like the United States, the European Commission, the United Kingdom and Japan" (CIGI Report, 2009, p.9). As a result, the Obama Administration focuses on a new strategy for Afghanistan that emphasizes coordination among international actors in the country.

\subsection{Corruption and Illicit Drug Issues}

Corruption and benefiting from drug trafficking within police forces, in Kabul and other provinces, are tremendous obstacles to reorganize the ANP through international organizations, the U.S. and, the Afghan government. According to the Afghanistan Security Report of the United States Government Accountability Office (2008), the 87 percent of weekly reports is related to corruption within the police force or the Minister of Interior. The report notes that the corruption includes bribery and misconduct which is very common in high ranking officials. Furthermore, in early 2007, the highway police was disbanded because of bribery and misconduct. Nonetheless, delaying in payments of the police salaries, sometimes several months, is an important factor 
Çiftçi, I., \& Kula, S. (2014). How security problem of Afghanistan threatens the global world: Afghan police reform case. International Journal of Human Sciences, 11(2), 1041-1061. doi: 10.14687/ijhs.v11i2.2925

pushing the police to accept a bribe. On account of the Minister of Interior`s traditional salary distribution system, the police chiefs skimmed their subordinates`salaries for themselves. In spite of the fact that the government has begun to pay all salaries via electronic fund transfer into bank account in order minimize skimming of salaries after 2008, the transfer has been only implemented in 12 of 34 provinces.

Afghanistan is the largest opium producer of the world, accounting for $92 \%$ of global production. Therefore, the counternarcotics effort of the Afghan government has limited effect on opium and heroin production. Illicit drug producing and trafficking provide incredible benefits for the tribal leaders, warlords, al-Qaeda, the Taliban, and other terrorist groups in Afghanistan and region. However, beyond funding terrorist groups and other criminal, the revenue from illicit drug producing and trafficking cause the wide spreading of corruption in all levels of the Afghan government. With regards to this problem, Perito states that "Interior Minister Officials, police chiefs, and member of ANP are involved with drug trade. Combination local loyalties, links of criminal networks, low or no pay, and residual culture of impunity contributed to endemic corruption in the ANP” (Perito, 2009, p. 6-7).

\subsection{Illiteracy}

The high rate of illiteracy in the Afghan National Police is another significant problem for the police reform. According to the NATO training mission, only 11 percent of the enlisted personnel in police are well trained ${ }^{4}$, less of 20 percent of them can read and write, compared to 35 percent for non-commissioned officers and 93 for the officer corps. Moreover, approximately 74 percent of the Afghan population is illiterate (Qadri, 2010). This high rate of illiteracy within the ANP is essential problem for the International powers that train police to increase their policing skills. The majority of training programs of the U.S. and donors persistently train new or current state police officers in classroom although those police have no classroom experience.

\subsection{U.S Withdrawal from Afghanistan}

In late 2001, with the fear of that Afghanistan's rival ethnic groups pulling apart any unitary state by using their regional power, U.S. forces expelled the Taliban from Afghanistan with the support of international community. The Obama administration announced the plan for the possible withdrawal of all U.S. troops by the end of the year 2014 if no security agreement between

\footnotetext{
${ }^{4}$ In Afghanistan, the author, İrfan Çiftçi, taught two classes that lasted three month; only 2 police officers of 60 could read and write. As result of this, the course was divided two sections; one section was related to policing skills, morning and afternoon; the other section was literacy training, in evening. Wardak Police Department liked this model police training which called Turkish Model Training by the U.S. provincial monitors.
} 
Çiftçi, İ., \& Kula, S. (2014). How security problem of Afghanistan threatens the global world: Afghan police reform case. International Journal of Human Sciences, 11(2), 1041-1061. doi: 10.14687/ijhs.v11i2.2925

Afghan and US officials is signed. Security responsibility will be transferred to the Afghan government at the end of 2014 (Barfield, 2011). The year of 2014 will be a transition date for Afghan politics. Obscurity remains for all fields, especially for security.

\section{Recommendations for Police Reform}

Despite of a lot of efforts of international organizations and donors, police building reform in Afghanistan have come across important problems. Due to the urgency of security issues in the country, there have been some shortcomings in the strategies that are follows (Murray, 2007, p.117). There are three main problems in police reform: attention gaps, knowledge gaps, and implementation gaps (Marenin, 2005).

One of the important example of attention gaps is related to insufficient strategy of the U.S. concerning to the ANP. The main aim of this strategy was to increase police numbers, provide more equipment, train new recruits and present police, and use the ANP in the fight against the Taliban insurgents. However, this strategy did not work because the U.S. ' strategy was not focusing on protecting Afghan civilians at the first period of American forces' presence. Nonetheless, although there are a lot of differences between the Afghan police and Afghan army, the U.S. approach has gradually militarized the Afghan police for nine years (Perito, 2009, p. 13). This is also significant challenge for the ANP because democratic policing in the world focuses to control crime and protect civilians. If the U.S. wants to succeed in the ANP reform, it should change the strategy after this period and focus on the sustainable security reform in Afghanistan. For this purpose, as a first step, the Afghan National Army (ANA) should be used in fighting against the heavily armed Taliban insurgents.

Regarding the knowledge gap in the police reform, Marenin suggests that police rebuilding reform often ignores the 'exciting' body of knowledge on the structure, nature, practices and cultures of policing (Marenin, 2005). Police training is a significant example of the "knowledge gap". Murray says that trainings are "largely developed and delivered by operational police. They know their métier functional roles and responsibilities but are not experienced trainers and have received little or no guidance from a professional trainer. The achievement of training objectives, such as knowledge transfer and competency development, is thus sabotaged by ineffective training methods, poor learning materials, bad examples and sometimes outdated information." Moreover, especially for the Afghan police it is really hard to learn something "from sitting on a hard seat in a classroom that is too hot in the summer and too cold in the winter, listening for several hours a day to an instructor speaking an unintelligible language, which has to be translated by, often untrained, interpreters uncertain of police terminology, without the support of words written in the local 
Çiftçi, İ., \& Kula, S. (2014). How security problem of Afghanistan threatens the global world: Afghan police reform case. International Journal of Human Sciences, 11(2), 1041-1061. doi: 10.14687/ijhs.v11i2.2925

language on the board, good training materials or any sort of audio-visual support"(Murray, 2007, p. 119).

Implementation gaps stem from frequently lack of coordination and different system policing. Whilst Germany in particularly and Norwegian arranges European system police training at the non-commission officer level, the U.S. gives lectures on common laws and policing principles at the military level (Murray, 2007, p. 121). Another problem is to implement different type of curriculum in police trainings. Therefore, all countries that performed efforts for training of the Afghan police should agree on a common curriculum which will bring the standardization for police trainings. International organizations and individual countries having bilateral agreements with Afghan government can arrange the same training program for whole country.

\section{Conclusion}

Domestic and international actors in the Afghan police reform have failed to discern between strategic, operational and political decision making. Currently, the Afghan Interior Ministry has not performed any noteworthy effort in supporting and overseeing the ANP, although the ANP operated under the ministry of interior. This problem stems from the lack of strategic and operational thinking. One of the main factors that will contribute to success is to provide ministerial support and supervision for the ANP that can operate effectively against insurgents and criminals in Afghanistan.

Besides, it is greatly significant to improve the criminal justice system of Afghanistan. As previously stated, Italy was responsible the law and justice reform in Afghanistan. However, until now, it is hard to mention that the justice reform has been effectively operated throughout the country by donor. The main reason is that operations for improving courts and prisons have fallen behind the enormous expenditures to rebuild the ANP. Therefore, "the ANP cannot perform effectively in the absence of the criminal justice system; courts and prisons" (Perito, 2009, p. 14).

In addition to security problems in Afghanistan, the high rate of illiteracy is the fundamental problem for both people and institutions, and international actors. All countries should agree to develop a comprehensive project that could solve this vital problem at the earliest level. If the U.S. and its allies can focus on illiteracy in the country at beginning of intervention, the problem will be solved following ten years. Otherwise, international actors and the Afghan government will not reach the basic human recourses standards for deploying the security forces.

Consequently, The U.S., NATO, and other international organizations will not be stay in Afghanistan forever. Since all U.S. troops are about to withdrawal by the end of the year 2014 if no security agreement between Afghan and US officials is signed, the US and the coalition forces 
Çiftçi, I., \& Kula, S. (2014). How security problem of Afghanistan threatens the global world: Afghan police reform case. International Journal of Human Sciences, 11(2), 1041-1061. doi: 10.14687/ijhs.v11i2.2925

should develop applicable, effective, and sustainable security reform that will be internalized by the Afghan people. Otherwise, it will be very difficult to maintain security in Afghanistan. Therefore, the security problem in Afghanistan will continue to threaten the global security.

\section{References}

Afghanistan Security Report. (2008). Afghanistan Security: Further Congressional Action May Be Needed to Ensure Completion of a Detailed Plan to Develop and Sustain Capable Afghan National Security Forces. GAO Reports, 1-71. doi: Article

Amnesty International Report. (2002). Afghanistan, Retrieved from http://www.amnesty.org/en/region/report-2007

Balcı, A. (2004). “Afganistan: UlusDevletve Kabilecilik Arasında” Dünya Catısma Bölgeleri, s. 262.

Barfield, T. (2011). Afghanistan's Ethnic Puzzle. Foreign Affairs, 90 (5), 54-65

CIGI Afghanistan Report. (2009). Security Sector Reform Monitor, Retrieved from http://www.ssrnetwork.net/uploaded_files/5000.pdf

Chesterman, S. (2002). Tiptoeing Through Afghanistan: The Future of UN State-Building, Retrieved from http://www.ipinst.org/publication/policy-papers/detail/150-tiptoeingthrough-afghanistan-the-future-of-un-statebuilding-simon-chesterman.html

Crisis Group Asia Briefing. (2008). Policing in Afghanistan: Still Searching a Strategy: Crisis Group Asia Briefing. Retrieved from http://www.crisisgroup.org/en/regions/asia/southasia/afghanistan/B085-policing-in-afghanistan-still-searching-for-a-strategy.aspx

Crisis Group Asia Report. (2007). Reforming Afghanistan's Police, Retrieved from http://www.crisisgroup.org/ /media/Files/asia/south-

asia/afghanistan/138_reforming_afghanistan_s_police.ashx

Ekşi, M. (2010). Turkey's Increasing Role in Afghanistan. Journal of Global Analysis, 1(2), 139-151.

Goodson, L. (2005). Bullets, Ballots, and Poppies in Afghanistan, Journal of Democracy, January 24-38, Retrieved from https://muse.jhu.edu/demo/journal_of_democracy/ v016/16.1goodson.html,

Hayes, G., \& Sedra, M. (2008). Security Sector Reform and State Building in Afghanistan: Transition under Threat, Wilfrid Laurier Univ. Press.

http://www.ntm-a.com. (2010). Afghan, NATO Officials Select Afghan Police Training Site in Turkey. Retrieved November 29, 2010, from http://www.ntma.com/blog/categories/police/1095-moi-and-ntm-a-turkey-visit-for-anp-training?lang=

Marenin, O. (2005). Restoring policing systems in conflict torm nations: Process, problems, prospects, Geneva Centre for the Democratic Control of Armed Forces.

Murray, T. (2007). Police-Building in Afghanistan: A Case Study of Civil Security Reform. International Peacekeeping (13533312), 14(1), 108-126. doi: Article

Murray, T. (2009). The Security Sector in Afghanistan, South Asian Survey, 16(2), 187 -208. doi:10.1177/097152310901600203

O'neill, W. G. (2005). Police Reform in Post-Conflict Societies: what we know and what we still need to know. NY: International Peace Academy. 
Çiftçi, I., \& Kula, S. (2014). How security problem of Afghanistan threatens the global world: Afghan police reform case. International Journal of Human Sciences, 11(2), 1041-1061. doi: 10.14687/ijhs.v11i2.2925

Pandya, A. (2007). "Security, Reconstruction and Political Normalization in Afghanistan" Retrieved from http://www.americanprogress.org/ AccountTempFiles/ cf/\%7BE9245FE4-9A2B-3C7A521-5D6FF2E06E03\%7D/ pandya.pdf

Rubin, Barnett; Hamidzada, Humayun and Stoddardr, Abby. (2003). "Through the Fog of Peace Building: Evaluating the Reconstruction of Afghanistan" Retrieved from http://www.cic.nyu.edu

Perito, R. M. (2009). Afghanistan's Police-The Weak Link in Security Sector Reform, Security and Development in Peace Operations and Post-Conflict Situations, 79

Qadri, A. (2010). Illiteracy in Afghanistan's military and police-Washington Times, Retrieved November 23, 2010, from http://www.washingtontimes.com/multimedia/collection/afghan-literacy/?page $=4$

Sedra, M. (2003). Police Reform in Afghanistan: An Overview. Brief 28, 32.

Shalizi, H. (2010). Karzai wants more equipment, trainers from NATO | Reuters. Retrieved November 25, 2010, from http://www.reuters.com/article/idUSTRE6AM29020101123

Shanahan, M. K. (2002). Security in Afghanistan: the International Security Assistance Force (IS AF), Henry L Stimson Center, Washington, DC, United States, Retrieved from http://www.isn.ethz.ch/isn/Digital-ibrary/Publications/Detail/?ots591=0c54e3b3-1e9cbe1e-2c24-a6a8c7060233\&lng=en\&id=31139

Thruelsen, P. D. (2010).Striking the Right Balance: How to Rebuild the Afghan National Police, Retrieved from https://login.mutex.gmu.edu/login?url=http://www.

informaworld.com $/$ smpp $/$ content $\sim$ content $=\mathrm{a} 920494816 \sim \mathrm{db}=$ all $\sim$ jumptype $=$ rss

USAID/Afghanistan. (2010). Provincial Reconstruction Teams, Retrieved November 29, 2010, from http://afghanistan.usaid.gov/en/Page.PRT.aspx

Wilder, A. R. (2007). Cops or Robbers: The Struggle to Reform the Afghan National Police, Afghanistan Research and Evaluation Unit. Retrieved from http://www.comw.org/warreport/fulltext/0707wilder.pdf

www.todayszaman.com. (2010). Karzai wants more equipment, trainers from NATO. Retrieved November 25, 2010, from http://www.todayszaman.com/news-227744-karzai-wantsmore-equipment-trainers-from-nato.html

www.isaf.nato.int. (2010). Troops Numbers and Contribution, Retrieved from http://www.isaf.nato.int/troop-numbers-and-contributions/index.php

Yilmaz, A. (2005). The Social Status and Religious Education of Women in Afghanistan, Retrieved from http://tez.sdu.edu.tr/Tezler/TS00416.pdf 